\title{
Prorok Agabos w Dziejach Apostolskich
}

\section{Wstẹp}

W tekście Dz temat proroctwa chrześcijańskiego pojawia się sześciokrotnie w różnych kontekstach bezpośrednich ${ }^{1}$. Niekiedy o prorokowaniu mówi się bardzo zdawkowo, bez wchodzenia w szczegóły, kiedy indziej prorokami są określani chrześcijanie, którzy pełnią różne funkcje w Kościele ${ }^{2}$. Szczególną rolę w tym szacownym gronie zdaje się odgrywać prorok Agabos, o którym wspomina się dwa razy: w Dz 11,27-30 oraz w 21,10-11. W Dz 11,27-28 epizod włączony jest w opis sytuacji pierwszej wspólnoty chrześcijańskiej Antiochii. Agabos pojawia się tu w otoczeniu innych, anonimowych proroków judejskich. W przypadku drugim (Dz 21,10-11) opis dotyczy spotkania Agabosa z Pawłem udającym się w ostatnią podróż do Jerozolimy. Temat proroka Agabosa cieszy się dziś umiarkowanym zainteresowaniem egzegetów. Dlatego wydaje się, że istnienie pewnej niszy interpretacyjnej jest pierwszym ważnym motywem, dla którego warto się tej postaci przyjrzeć nieco bliżej. Dodatkowo za analizą teologiczno-biblijną postaci Agabosa przemawiają przynajmniej trzy względy:

- Agabos jako jedyny prorok chrześcijański pojawia się dwa razy w zupełnie różnych pod względem strukturalnym tekstach Dz;

- w obydwu przypadkach Agabos pozostaje w mniej lub bardziej ścisłym związku z historią Pawła;

${ }^{1}$ Dz 11,27-28; 13,1-3; 15,32; 19,6; 21,9 oraz 21,10-11.

${ }^{2}$ Zob. M. Karczewski, Prorocy chrześcijańscy w Dziejach Apostolskich, w: „Bóg jest miłościq" (1J 4,16), Fs. J. Kudasiewicz (RSB 25), red. W. Chrostowski, Warszawa 2006, 175-195. Poniższy artykuł częściowo bazuje na wcześniejszej publikacji. Zawiera jednak wiele uzupełnień, szczególnie bibliograficznych. Podstawowym przedmiotem pogłębionego studium jest postać tylko jednego z proroków, Agabosa. 
- przedstawia się go jako profetę głoszącego bardzo konkretne proroctwa dotyczące przyszłości.

Jako przygotowanie do analizy egzegetycznej tekstów związanych bezpośrednio z prorokiem Agabosem pragniemy krótko scharakteryzować pozostałe teksty związane z tematem proroctwa chrześcijańskiego w Dz.

\section{Pozostali prorocy chrześcijańscy w Dziejach Apostolskich}

\subsection{Prorocy w Antiochii (13,1-3)}

W pierwszym z tekstów dotyczących proroków chrześcijańskich, niezwiązanych z Agabosem, w Dz 13,1-3 sugeruje się, że do grona proroków i nauczycieli należeli Szaweł i Barnaba. Fragment Dz 13,1-3 stanowi wstęp do pierwszej podróży apostolskiej Pawła $(13,4-14,28)^{3}$. W 13,1 przedstawieni są pro-

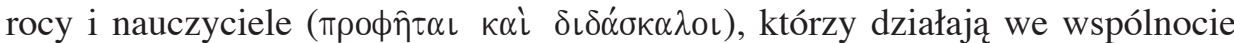
chrześcijańskiej w Antiochii (por. 11,28). Pośród pięciu imion jako pierwszy zostaje wymieniony Barnaba, natomiast jako ostatni - Szaweł ${ }^{4}$. Termin ,nauczyciele" $-\delta\left\llcorner\delta \alpha ́ \sigma \kappa \alpha \lambda \circ \iota^{`}\right.$ występuje tu jedyny raz w Dziejach. Umieszczenie proroków i nauczycieli na początku opowiadania może podkreślać ich pozycję w strukturze wspólnoty antiocheńskiej. Z pewnością posiadają na nią konkretny wpływ. $\mathrm{Z}$ drugiej strony, proste stwierdzenie, że prorocy i nauczyciele kierują wspólnotą, nie jest przesądzone, ponieważ treść następnych wersetów wskazuje na wydarzenie charyzmatyczne osadzone w kontekście liturgicznym ${ }^{5}$. W 13,2 zawarty jest istotny opis działania Pięciu w Antiochii. Koncentracja terminologii związanej

\footnotetext{
${ }^{3}$ Na temat relacji 13,1-3 do całości 13,1-15,35: U. Borse, Lukanische Komposition in Umfeld der ersten Missionsreise, SNTU 11 (1986) 169-194.

4 Proponuje G. Schneider, Gli Atti degli Apostoli, t. 2, 146-147. E. Hänchen (Die Apostelgeschichte, Göttingen 19777, 356) myśli o oddaleniu imion Barnaby i Szawła jako przygotowaniu na to, co nastąpi. Zob. również H. Schürmann, „...und Lehrer. Eine geistliche Eigenart des Lehrdienstes und sein Verhältnis zu anderen geistlichen Diensten im neutestamentichen Zeitalter”, w: Orientierung an Neuen Testament, Düsseldorf 1978, 133; R. Schnackenburg, La Chiesa nel Nuovo Testamento, Milano 1973, 67-70; F. Asensio, Los colaboradores de Pablo, Burgense 33 (1992) 329-380; K. Romaniuk, Wokót Ewangelii i listów św. Pawła, Warszawa 2002, 345.

${ }^{5}$ Zob. W. Rakocy, „Będziecie moimi świadkami...” (Dz 1,8). Dzieje Apostolskie, w: Dzieje Apostolskie. Listy św. Pawła (WMWKB 9), red. J. Frankowski - S. Mędala, Warszawa 1997, 61; K. Romaniuk - A. Jankowski - L. Stachowiak, Komentarz Praktyczny do Nowego Testamentu, Poznań - Kraków 1998, 655.
} 
z liturgią prowadzi niektórych egzegetów do wprowadzenia nowej jakości - proroka-liturga, który w Antiochii miałby odpowiadać za kult ${ }^{6}$. Podczas służby Bożej przemawia sam Duch Święty. On jest prawdziwym Przewodnikiem oraz Panem wspólnoty. Nakaz Ducha jest jasny i wyraźny. Barnaba i Szaweł powinni zostać wyłączeni z innych zdań i przeznaczeni do specjalnej misji ${ }^{7}$. Postępowanie według wskazań Ducha Świętego (Dz 13,3) jest podstawową cechą działania autentycznego ${ }^{8}$ proroka chrześcijańskiego.

\subsection{Juda i Sylas jako prorocy $(15,32)$}

W Dz 15,32 miejsce akcji stanowi ponownie Antiochia. Razem z Pawłem i Barnabą przybywają z Jerozolimy Juda i Sylas. Podczas zgromadzenia zostaje odczytany list od Apostołów wydany z okazji soboru jerozolimskiego (ww. 23-31). Przesłanie soboru stanowi tło przyjęcia listu. Pomiędzy chrześcijanami pochodzenia żydowskiego i pogańskiego zdaje się panować doskonała harmonia. Tym razem funkcję proroków chrześcijańskich pełnią właśnie Juda i Sylas,

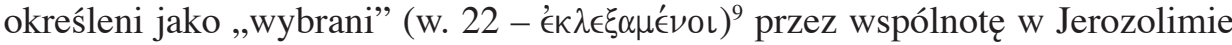
do towarzyszenia Pawłowi i Barnabie. Dodatkowo w 15,22 o Judzie i Sylasie

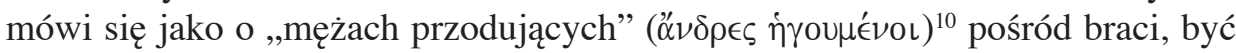

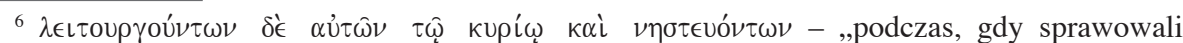
liturgię i pościli”. O prorokach-liturgach wspomina S. Dockx, L'ordination de Barnabé et de Saul d'aprés Actes 13,1-3, NRTh 98 (1976) 242. Na szczególne znaczenie służby liturgicznej w kontekście kontaktów terminologicznych związanych z Septuagintą wskazuje H. Marshall, Acts, w: Commentary in the New Testament Use of the Old Testament, red. G.J. Beale - D.A. Carson, Grand Rapids 2007, 582.

${ }^{7}$ Czy jest to nadal misja prorocka? Czy może „również” prorocka? Niektórzy egzegeci, próbując zdefiniować charakter prorockiej posługi Pawła (Dz 13,1) podkreślają znaczenie faktu powołania, które miałoby posiadać znamiona powołania prorockiego, zob. K.D. Litwak, Israel's Prophets Meet Athens' Philosophers: Scriptural Echoes in Acts 17,22-31, Bib 85 (2004) 199-200.

${ }^{8}$ Bezpośrednio po wyruszeniu w drogę prorocy i nauczyciele, Barnaba i Saul, spotykają innego proroka i nauczyciela, który jest prorokiem fałszywym. Konfrontacja uwidacznia różnicę, zob. Dz 13,6-12 oraz R. Strelan, Who War Bar Jesus (Act 13,6-12), Bib 85 (2004) 71.

922 razy w Nowym Testamencie: Mt - 0 razy, Mk - 1 raz, Łk - 4 razy, 5 razy u J, 7 razy w Dz, 4 razy u Pawła, Jk - 1 raz. W kontekście dzieła Łukaszowego używa się go np. w odniesieniu do wyboru Dwunastu (Łk 6,13), Jezusa (9,35), Marii, siostry Marty (10,42); czy miejsc przy stole $(14,7)$, por. Dz $1,2.24 ; 6,5 ; 13,17 ; 15,7.22 .25$. Rzadkie użycie terminu greckiego u Łukasza wskazuje, że chodzi o wybraństwo w sensie bardzo pozytywnym, wyróżniającym.

${ }^{10}$ Tylko raz u Łk, 4 razy w Dz. Jako hapax legomenon w Nowym Testamencie u Łk występuje

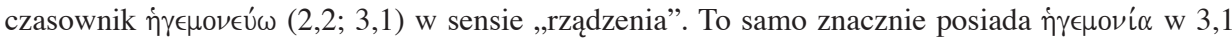
(także tu hapax). W tej samej linii tematycznej „rządzić, być u władzy” pozostaje rzeczownik

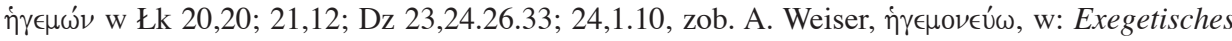


może kierujących wspólnotą. Juda i Sylas są, podobnie jak Paweł i Barnaba,

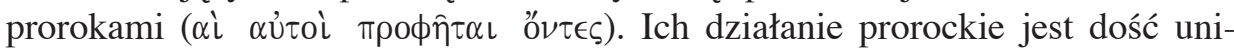
wersalne i nie posiada żadnych cech wyjątkowych, ponieważ jako prorocy licznym słowem upominali i zachęcali braci.

\subsection{Uczniowie Jana $(19,6)$}

Po raz kolejny prorokowanie w wykonaniu chrześcijan jest wspomniane w Dz 19,6. Werset stanowi część jednostki 19,1-7. Miejscem akcji jest Efez, natomiast głównymi bohaterami - Paweł i ,jacyś" uczniowie $(19,1)$. W centrum zainteresowania znajduje się dar Ducha Świętego, rozważany na tle jakości chrztu. Chrzest Jana, który przyjęli spotkani przez Pawła uczniowie, jest niewystarczający (ww. 3-4), ponieważ nie udziela daru Ducha ${ }^{11}$. Paweł nakłada na nich ręce i dokonuje chrztu w imię Jezusa (w. 6). Nowoochrzczeni mówią

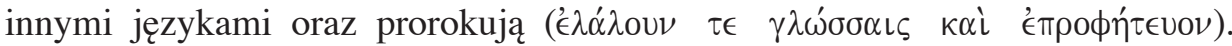
Z pewnością Dz 19,1-7 nawiązuje do 18,24-28 - tekstu związanego z postacią Apollosa. Jego imię pojawia się ponownie w Dz 19,1. Obecność innych uczniów, którzy podobnie jak on znali tylko chrzest Janowy, świadczy o tym, że problem uzupełnienia chrztu dotykał szerszej liczby osób. Na czym miałoby polegać prorokowanie uczniów Jana, nie wiadomo. Bezpośredni kontekst wzmianki odkreśla manifestację charyzmatyczną jako dowód rzeczywistego działania Ducha Świętego.

\subsection{Córki Filipa $(21,9)$}

Paweł zmierza do Jerozolimy. Odwiedzając lokalne wspólnoty chrześcijańskie, zachowuje się tak, jak gdyby działo się to po raz ostatni (zob. 20,18-35; 21,13). Przekonanie to udziela się odwiedzanym chrześcijanom (zob. 20,37-38; 21,4; 11). Mimo to Paweł jest przekonany, że udając się do Jerozolimy, wypełnia wolę Bożą (zob. 19,21; 21,13). W tym kontekście pełnym atmosfery rozstania i nieprzewidywalnego zła, które oczekuje Pawła, pojawiają się dwie kolejne

Woerterbuch zum Neuen Testament [= EWNT], red. H. Balz - G. Schneider, t. II, Stuttgart 1992², 278-279; T. Schramm, i $\gamma \gamma^{\prime} \circ \mu \alpha \iota$, w: EWNT II, 280.

${ }^{11}$ Zob. F.W. Norris, Christians only but not the only Christians (Acts 19,1-7), ResQ 28 (1985/86) 97-105; M. Wolter, Apollos und die ephesinischen Johannesjünger (Apg 18,24-19,7), ZNW 78 (1987) 49-73; H. Lichtenberger, Täufergemeinde und die frühchristliche Täuferpolemik im letzten Drittel des 1. Jas.hrhunderts, ZTK 84 (1987) 36-57; J. Jervell, Die Apostelgeschichte, Göttingen 1998, 274. 
wzmianki o prorokach - czterech córkach ewangelisty Filipa oraz przybyłego do Cezarei Agabosa.

Córki Filipa zostały określone jako dziewice prorokujące ( $\pi \alpha \rho \theta \in$ є́

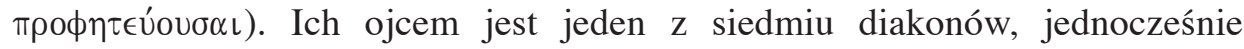
nazywany ewangelistą (zob. 6,5; 8,4-13.25-40; Ef 4,11; 2 Tm 4,5) ${ }^{12}$. Termin $\pi \alpha \rho \theta^{\prime} \nu$ or oznacza dziewczyny, młode kobiety, dziewice zdolne do zawarcia małżeństwa ${ }^{13}$. Bardzo istotne jest użycie czasownika w formie imiesłowu czasu

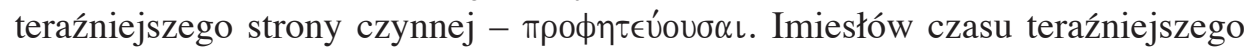
może sugerować trwanie, kontynuację w czasie realizowanego działania ${ }^{14}$. Można zatem przypuszczać, iż chodzi o cztery młode, niezamężne kobiety, które posiadały stałą zdolność wypowiadania proroctw ${ }^{15}$. Łukasz nie rozwija jednak tego tematu, nie nazywa ich wprost prorokiniami (jedynie w Łk 2,36; Ap 2,20). Fakt obecności kobiet, które prorokują, współbrzmi bardzo dobrze z przekonaniem o wypełnianiu się cytowanego proroctwa Joela (zob. Dz 2,17-18) ${ }^{16}$. Dodatkowo jedną z cech charakterystycznych eklezjologii Łukasza jest zwrócenie uwagi na obecność i działanie kobiet ${ }^{17}$. Kobiety spełniają szczególną misję w życiu Jezusa, w misterium paschalnym oraz w początkach Kościoła. Podobnie jak mężczyźni mają one udział w życiu Kościoła. Inaczej, ale w sposób równie istotny, wspierają dzieło ewangelizacji.

\subsection{Podsumowanie}

Prorocy chrześcijańscy wymienieni bezpośrednio przez Łukasza w Dz tworzą trzy wyraźne grupy ${ }^{18}$. Jedna z nich to prorocy pochodzący z Judei lub Jerozolimy.

${ }^{12}$ Niektórzy sugerują, że to właśnie Filip zakładał wspólnotę w Cezarei (por. 8,40), zob.: G. Schneider, Gli Atti degli Apostoli, t. 2, 401; B. Domagalski, Waren die Sieben (Apg 6,1-7) Diakone?, BZ 26 (1982) 21-33.

1315 razy w Nowym Testamencie, u Łk tylko 2 razy w odniesieniu do Maryi $(1,27)$, i w Dz jedynie tutaj. Słynny traktat dotyczący dziewic przedstawia Paweł w 1 Kor 7. Inne lokalizacje biblijne, również o zabarwieniu symbolicznym - zob. Mt 25,1.7.11; 2 Kor 11,2; Ap 14,4.

${ }^{14}$ Zob. F. Blass - A. Debrunner, Grammatik des neutestamentlichen Griechisch, Göttingen 1990 ${ }^{17}, \S 318.339$. [dalej jako Blass-Deb].

15 Forma czasownikowa może sugerować, że prorokowały one regularnie lub proroctwo należało do natury ich posługi twierdzi C.S. Keener, Komentarz historyczno-kulturowy do Nowego Testamentu (PSB), Warszawa 2000, 288.

${ }^{16}$ C.S. Keener (Komentarz historyczno-kulturowy, 288) jako daleką analogię wskazuje Testament Hioba, wedle którego córki Hioba miały posiadać również zdolności prorocze.

${ }^{17}$ Jest to ewidentne w różnych licznych tekstach zob. B. Prete, L'opera di Luca. Contenuti e prospettive, Leumann 1986, 468-472; P. Grelot, La donna nel Nuovo Testamento, Cinisello Balsamo 1996, 85-90.

${ }^{18}$ Zróżnicowanie w ujęciu kwestii profetyzmu chrześcijańskiego w Dz podkreśla W. Rakocy, „Będziecie moimi świadkami...” (Dz 1,8), 61. 
Należą do nich Juda i Sylas oraz Agabos - anonimowi prorocy z Judei, którymi zajmiemy się poniżej (zob. 11,27-30; 15,32; 21,10). Drugą tworzą prorocy i nauczyciele działający we wspólnocie chrześcijańskiej w Antiochii $(13,1)$. Trzecia grupa to osoby spełniające jakieś funkcje prorockie, jednakże brak dokładnych danych uniemożliwia ich dokładniejsze określenie. Jest to prorokowanie ochrzczonych w imię Jezusa uczniów Jana $(19,6)$ oraz obecność prorokujących dziewic w domu ewangelisty Filipa w Cezarei $(21,9)$.

Prorocy judejscy są prorokami, którzy ,przybywają”, tzn. prorokują poza własną wspólnotą. Sylas i Juda są prorokami niejako dodatkowo, ponieważ przede wszystkim są współodpowiedzialnymi za wspólnotę w Jerozolimie.

Druga grupa proroków to osoby posiadające ważną pozycję we wspólnocie antiocheńskiej $(13,1)$. Ich posługa wiąże się z kontekstem liturgicznym w rodzimej wspólnocie. W wyniku bezpośredniego nakazu Ducha Świętego, który również może być zdefiniowany jako efekt proroctwa, dwóch z nich zostaje posłanych do pracy misyjnej. Bycie prorokiem nie jest zatem ekskluzywne. Prorok może być równocześnie nauczycielem i apostołem. Kontekst prorocki początków działalności apostolskiej Pawła uwydatnia, iż jego misja jest realizacją planów Bożych i w konsekwencji tego to Duch Święty, a nie jakakolwiek władza ludzka, kieruje Kościołem.

Podobne podporządkowanie tematu proroctwa szerszemu kontekstowi teologicznemu zauważa się w wydarzeniu z Efezu. Prorokowanie połączone z mówieniem językami w Efezie jest przede wszystkim widzialnym znakiem potwierdzającym udzielenie chrztu chrześcijańskiego ${ }^{19}$. W perspektywie nowej powszechności daru Ducha mieszczą się także córki Filipa, o których wiadomo, że prorokują, ale nic ponadto. Są kobietami, lecz dar Ducha nie zna ani granic płci, ani żadnych innych. Przeciwnie, kobiety odgrywają w Kościele istotną rolę.

\section{Agabos - prorok z Judei}

\subsection{Teksty o Agabosie w strukturze Dz}

Księga Dziejów Apostolskich należy do grupy tekstów nowotestamentowych o wyjątkowo złożonej historii kompozycji. Uderza wielość wariantów tekstu oraz złożony proces jego redakcji. Tym nie mniej zwroty narracji, ewidentne zmiany

${ }^{19}$ Zob. R. Schnackenburg, Die Person Jesu Christi, 189-192. 
stylistyczne, zmiana głównych bohaterów wydarzeń, miejsc akcji czy istnienie wyraźnych bloków tematycznych sugerują możliwe strukturyzacje $\mathrm{Dz}^{20}$. Można również zauważyć, że w treści Dz znajduje się kilka wyraźnych zwrotów na poziomie zawartej w nich tematyki ${ }^{21}$. Powoduje to, że liczni egzegeci rozpoznają w treści księgi co najmniej kilka równorzędnych, autonomicznych jednostek literackich ${ }^{22}$. Stosując powyższą logikę, można zaproponować dość wyraźnie zarysowany podział księgi, który opiera się prawie całkowicie na propozycjach Rudolfa Pescha ${ }^{23}$.

Pierwsza relacja dotycząca proroka Agabosa, Dz 11,27-30, stanowi część pierwszego głównego bloku księgi (Dz 2-15). Wstęp do zasadniczej treści bloku Dz 2-15 stanowią opisy wniebowstąpienia (1,1-11) ${ }^{24}$ oraz modlitewnego oczekiwania na dar Ducha Świętego $(1,12-26)^{25}$. Od wydarzeń Pięćdziesiątnicy $(2,1)$ rozpoczyna się pierwsza część księgi, która kończy się wraz z soborem jerozolimskim $(15,35)$. Chociaż niektórzy egzegeci proponują inne strukturyzacje tekstu, znaczna ich większość jest zgodna, że w 15,36 rozpoczyna się nowa część księgi. Wzmianka o Agabosie jest umieszczona w kontekście Dz 8,4-12,25, czyli relacji z pierwszych akcji misyjnych, które następują po męczeńskiej śmierci Szczepana (Dz 6,8-8,3). Narrację otwiera opis misji Filipa oraz Piotra i Jana w Samarii (Dz 8,4-25). Następują kolejne epizody: nawrócenie Szawła (Dz 9,1-30), podróż Piotra do Liddy i Jaffy (Dz 9,32-43), nawrócenie i chrzest Korneliusza (Dz 10,1-18), dyskusje Piotra z judeochrześcijanami w Jerozolimie po skutecznym zwróceniu się Piotra do pogan (Dz 11,118). Opis powstania wspólnoty chrześcijańskiej w Antiochii (Dz 11,19-26) bezpośrednio poprzedzony jest epizodem przybycia Agabosa wraz innymi prorokami z Judei do Antiochii - Dz 11,27-30. Według niektórych komentatorów, Dz 11,27-30 stanowi integralną część charakterystyki wspólnoty antiocheńskiej

${ }^{20}$ Zob. F. Neirynck, Le Livre des Actes dans les récents commentaires, EThL 59 (1983) 338-349.

${ }^{21}$ Takim istotnym zwrotem w przepowiadaniu jest np. skierowanie słowa Ewangelii ku poganom (zob. 14,27; 28,28). Zwrot ten może okazać się kluczem do odkrycia intencji autora, na której bazuje konstrukcja literacka Dz. Na przykład po opowiadaniu o Szczepanie $(6,8-8,3)$ już wspomina Szawła $(7,58)$, który potem staje się „wybranym narzędziem” $(9,15)$ oraz apostołem pośród hellenistów $(11,19-12,24)$. Także historia Piotra zostaje poddana podobnemu zwrotowi, gdy zmienia się kierunek jego misji apostolskiej (zob. 10,1-11,18).

${ }^{22}$ Zob. F.F. Bruce, The Book of the Acts (NICNT), Grand Rapids 1988, vii-xiv; J.A. Fitzmyer, Acts of the Apostels (AB 31), New York 1998, 119-123; D.F. Bock, Acts, Grand Rapids 2007, vii-viii.

23 Propozycja ta w przeważającej części bazuje na obserwacjach R. Pescha, Die Apostelgeschichte, 39-41.

${ }^{24}$ Inaczej u E. Hänchena (Die Apostelgeschichte, 9), który jako wprowadzenie widzi 1,1-14.

25 J. Dupont (Les Actes des Apôtres, w: La Sainte Bible, Paris 1964³, 12.) rozpoznaje tu początek pierwszej części księgi (1,12-5,42). Podobnie w: G. Schneider, Gli Atti degli Apostoli, t. 1, Brescia 1985, 722. 
(Dz 11,19-30 ${ }^{26}$. Bezpośrednio po nim następuje zmiana zarówno miejsca akcji, jak i głównych bohaterów ${ }^{27}$. Autor Dz przedstawia sytuację Kościoła w Jerozolimie bezpośrednio przed śmiercią Heroda Antypasa (Dz 12,1-25). Werset 12,25, mówiąc o powrocie Barnaby i Szawła do Antiochii, nawiązuje do treści pierwszego epizodu z prorokiem Agabosem.

Druga wzmianka o proroku Agabosie pojawia się w drugim podstawowym bloku Dz, w rozdz. 15,36-28,16. Poprzedzają ją relacje z drugiej (Dz 15,3618,22) i trzeciej podróży misyjnej Pawła (Dz 18,23-19,20). Kontekst bezpośredni tworzy opis podróży Pawła do Jerozolimy (Dz 19,21-21,14). Pod koniec tej podróży Paweł zatrzymuje w Cezarei Nadmorskiej (Dz 21,8-14) ${ }^{28}$. Tam właśnie spotyka Agabosa - Dz 21,10-11. To, co następuje potem (szczególnie stan uwięzienia Pawła), aż do końca Dz pozostaje w ścisłym związku w proroctwem Agabosa. Są to relacje z pobytu Pawła w Jerozolimie i Cezarei $(21,15-26,32)$ oraz jego podróży do Rzymu i pobytu w nim (27,1-28,31).

\subsection{Dwa pojawienia siẹ Agabosa}

\subsubsection{Dz $11,27-30$}

W tych zaś dniach zeszli z Jerozolimy do Antiochii prorocy. Jeden z nich imieniem Agabos przepowiedział za sprawq, że nadchodzi wielki głód, który nastat za Klaudiusza. Uczniowie więc według możliwości, pośpieszyli, każdy z nich, by posłać pomoc braciom mieszkającym w Judei. Tak też uczynili posyłajac starszym (prezbiterom) przez Barnabe i Pawła.

Wewnętrzna struktura epizodu opisanego w Dz 11,27 jest bardzo przejrzysta. Po wprowadzeniu, które łączy wydarzenie z Antiochii z poprzedzającym je kontekstem (w. 27a), narrator zajmuje się nowym wydarzeniem. Jest nim przybycie i działanie proroków (ww. 27b-28). Przemawia jedynie Agabos, przekazując informację o nadchodzącym okresie głodu (w. 28). Drugą część stanowi opis

${ }^{26}$ J. Dupont, Les Actes des Apôtres, 14; G. Schneider, Gli Atti degli Apostoli, t. 2, 581. Według R. Pescha (Die Apostelgeschichte, 40), Dz 11,27-30 tworzą samodzielną jednostkę literacką. Por. W. Schmithals, Die Apostelgeschichte des Lukas, Zürich 1982, 111-114.

${ }^{27}$ O sekcji 11,30-20,38 obejmującej wszystkie podróże Pawła mówi W. Rakocy, „Będziecie moimi świadkami...” (Dz, 1,8), 44.

${ }^{28}$ W. Schmithals, Die Apostelgeschichte des Lukas, 191-193; G. Schneider, Gli Atti degli Apostoli, t. 2, 581; E. Hänchen, Die Apostelgeschichte, 573-580; J. Dupont, Les Actes des Apôtres, 181-183. 
reakcji słuchaczy (ww. 29-30). Polega ona na spontanicznej zbiórce środków i przesłaniu ich do Jerozolimy za pośrednictwem Barnaby i Pawła.

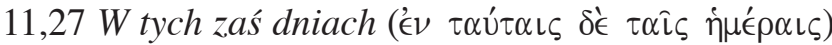

Formuła wprowadzająca - „w tych dniach”29 (w. 27) - łączy ściśle wydarzenia z początkami wspólnoty antiocheńskiej (11,19-26). Pozytywnym skutkiem prześladowań, które wybuchły w Jerozolimie, jest spontaniczna, ale udana misja ewangelizacyjna $\mathrm{w}$ jednym $\mathrm{z}$ głównych miast Imperium Rzymskiego - Antiochii ${ }^{30}$ (por. 11,19-21.24). Istotną część tworzącej się wspólnoty tworzą

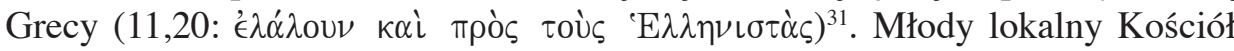
otrzymuje wsparcie z Jerozolimy w postaci Barnaby, który utwierdza w wierze świeżo nawróconych $(11,22-24)$. Barnaba sprowadza z Tarsu Szawła, który od niedawna jest zwolennikiem wyznawców Chrystusa i przez rok pracują razem w Antiochii (11,25-26). Właśnie ta wielokulturowa, hellenistyczno-żydowska

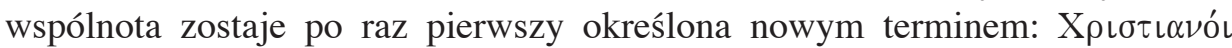
- „chrześcijanie”.

zeszli z Jerozolimy do Antiochii prorocy (

Po raz pierwszy autor $Ł k-D z$ podejmuje wprost temat proroków chrześcijańskich. Brak rodzajnika przed terminem $\pi \rho \circ \emptyset \eta\rceil \alpha \iota$ sugeruje, że chodzi o proroków bliżej nieznanych. Prorocy ci zeszli z Jerozolimy. Wspólnota w Jerozolimie, zjednoczona wokół Apostołów, szczególnie w pierwszej części księgi odgrywa, według autora ${ }^{32} \mathrm{Dz}$, bardzo ważną rolę (zob. 1,1-8,13;

${ }^{29}$ Zob. 1,$15 ; 6,1$.

${ }^{30}$ Antiochia Syryjska nad rzeką Orontes, uważana za trzecie co do wielkości miasto cesarstwa (po Rzymie i Aleksandrii). W I w. zamieszkiwało ją szacunkowo 500 tys. mieszkańców. Kwatera główna wojsk rzymskich na prowincję: Syria. Miasto wielokulturowe, mieszkańcy praktykowali liczne kulty religijne, istniała także liczna grupa Żydów i prozelitów, zob. C.S. Keener, Komentarz historyczno-kulturowy, 262. O wysokim stopniu urbanizacji Azji w I-II w. oraz o największych jej miastach, tym razem o Efezie, Smyrnie i Pergamonie wspomina M. Jaczynowska, Historia starożytnego Rzymu, Warszawa 19845, 273-274.

31 Warto zauważyć, że w Biblii o Antiochii Syryjskiej wspomina się tylko w Księgach Machabejskich (por. 1 Mch 3,27; 4,35; 6,63; 10,68; 11,13; 2 Mch 4,33; 5,21; 8,35; 11,36; 13,23.26; 14,27) i w Dziejach (11,19.22.26.27; 15,22-23). W pierwszym przypadku Antiochia jest stolicą Syrii, która pod panowaniem Seleucydów stała się głównym przeciwnikiem religijnym i politycznym Judei. Paradoksalnie, duchowi spadkobiercy hellenistów należą do pierwszych wyznawców chrześcijaństwa poza Palestyną. W Antiochii istniała także wspólnota żydowska, por.: R. Iori, Autorità, Carisma e Ministero nelle prime comunità cristiane, Roma 1993, 42-43; W. Rakocy, „Będziecie moimi świadkami...” (Dz 1,8), 36-37.

${ }^{32}$ Najprawdopodobniej autor sam pozostawał w ścisłym związku ze wspólnotą w Antiochii, W. Rakocy, Obraz i funkcja faryzeuszy $w$ dziele Łukaszowym (Łk-Dz). Studium literackoteologiczne, Lubin 2000, 173. 
$12,1-24 ; 15,1-30)^{33}$. Jest ona niejako matką wszystkich tworzących się wspólnot chrześcijańskich. Prawdopodobnie wymienieni prorocy również pochodzą

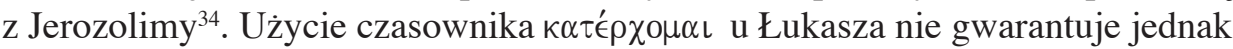
sensu pochodzenia ${ }^{35}$. Nie jest też zupełnie jednoznaczne, czy jest to grupa tzw. proroków wędrownych ${ }^{36}$. Przybycie grupy zaangażowanych, charyzmatycznie wierzących z Jerozolimy do Antiochii wyraża zależność nowej wspólnoty od centrum. Jednocześnie jest wyrazem więzi i zaangażowania wspólnoty jerozolimskiej w rozwój siostrzanej wspólnoty w Jerozolimie.

\section{1,28: Powstawszy zaś jeden z nich imieniem Agabos...}

Jeden z proroków powstaje ( $\alpha \nu \alpha \sigma \tau \dot{\alpha} \varsigma)$. Jest to postawa, która podkreśla wagę przemówienia lub działania ${ }^{37}$. Nie mówi się jasno, czy cała scena dokonuje się w kontekście zebrania liturgicznego ${ }^{38}$. Sprecyzowanie liczby przybyłych proroków jest niemożliwe. Wymienia się tylko jednego. Nie wiadomo, czy zabiera głos w imieniu grupy, czy w sposób zupełnie spontaniczny. Jego imię - Agabos ("A $\gamma \alpha \beta$ s) - jest odosobnione w Nowym Testamencie i występuje jeszcze tylko w Dz 21,10. Jego znaczenie niektórzy wiążą z „szarańczą” lub przymiotnikiem „bystry, inteligentny”39.

${ }^{33}$ Jest to wspólnota bardzo dobrze zorganizowana, obok Apostołów służą w niej prezbiterzy $(11,30 ; 15,2.4 .22 ; 16,4$. 21,18, por. 14,$23 ; 20,17)$ i diakoni $(6,1-6)$. W pewnym sensie wspólnota jerozolimska jest wzorcową, stąd czytając Dz, można mieć wrażenie, że jest przedstawiana bardzo idealistycznie, por. M. Moreland, The Jerusalem Community in Acts: Mythmaking and the Sociorethorical Functions of a Lukan Setting, w: Contextualizing Acts: Lukan Narrative and Greco-Roman Discourse (SBL.SymS 18), red. T.C. Penner - C.Vander Stichele, Atlanta 2003, 285-310.

${ }^{34}$ Zob. R. Schnackenburg, Die Person Jesu Christi im Spiegel der vier Evangelien, Freiburg Basel - Wien 1993, 177-179.

${ }^{35}$ Pochodzenie mogłoby oznaczać jedynie u Jk 3,15, zob. W. Bauer, Griechisch-deutsches Wörterbuch, Berlin - New York 1988, 858, [dalej jako WB]. Poza tym w Nowym Testamencie termin ten pojawia się jedynie u Łukasza, 2 razy w Łk i 13 razy w Dz.

${ }^{36}$ Sugeruje to Schneider, jednakże nie przedstawia argumentów przekonywujących. Argument, że również w Didache 11,7-12 mówi się o prorokach wędrownych, jest interesujący. Jednak, jak zauważymy poniżej, pomimo pewnych podobieństw pomiędzy pismami Łukasza i Didache, istnieją również istotne różnice. Zob. także: G. Schneider, Gli Atti degli Apostoli, t. 2, 123; R. Pesch, Die Apostelgeschichte, 356; G. Fascher, Profetes, 187-188; T. Schmeller, Brechungen. Urchristliche Wandercharismatiker im Prisma soziologisch orientierter Exegese (SBS 136), Stuttgart 1989, 83-87.

${ }^{37}$ Zob. 1,$15 ; 5,17 ; 5,34 ; 6,9 ; 13,16$, itd.

${ }^{38}$ Tak sugeruje Dupont, który podkreśla także, że być może chodzi tu o użycie hebraizmu dla podkreślenia początku proroctwa, zob. J. Dupont, Les Actes des Apôtres, 114, nota e.

${ }^{39}$ O pierwszej możliwości mówi Hänchen, powołując się na Wendta. Przedstawia jednak także inne możliwości tłumaczeń, wynikające ze starożytnej greki, zob. E. Hänchen, Die Apostelgeschichte, 359. O problemie ewentualnego pochodzenia imienia „Agabos” świadczy fakt pomijania tej kwestii w wielu znaczących słownikach egzegetycznych. W większości z nich 
Możliwe odniesienie do formy semickiej nie przeszkodziło w nadaniu imieniu formy greckiej ${ }^{40}$.

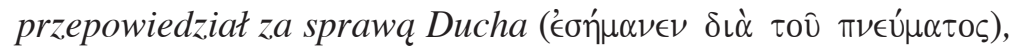

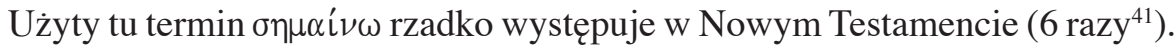
Jednakże jego znaczenie w tym kontekście nie budzi większych wątpliwości. Agabos działa pod natchnieniem Ducha Świętego i przepowiada przyszłość. Termin $\pi \nu \in u ́ \mu \alpha$ odnosi się do Ducha Świętego, który w Dziele Łukaszowym spełnia szczególną rolę. Jest animatorem ${ }^{42}$, prawdziwym kierującym Kościołem chrześcijańskim.

że nadchodzi wielki głód, który nastał za Klaudiusza.

Nadejdzie wielki głód ${ }^{43}$. Wyrażenie opisowe $\mu^{\prime} \in \lambda \lambda \in \iota \nu$ "€ $\sigma \in \sigma \theta \alpha \iota$ podkreśla

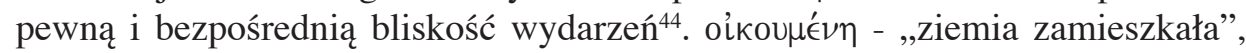
czyli świat, jest jednym z ulubionych terminów Łukasza ${ }^{45}$. Proroctwo dotyczyło przyszłości i, według Łukasza, wypełniło się za panowania cesarza Klaudiusza (41-54 r. po Chr.). Trudno, bez wnikania w zawiłe dyskusje historyczne wskazać jednoznacznie datę nadejścia kataklizmu. Z pewnością za panowania Klaudiusza imperium rzymskie nawiedziła cała seria nieurodzajów (w Palestynie w latach 46-48) ${ }^{46}$. W chronologii Dz proroctwo Agabosa wyprzedza zdarzenia, które

traktuje się termin „Agabosl tylko jako imię własne, pozbawione szerszych aluzji. Interesujące, że w słynnym Theologisches Woerterbuch zum Neuen Testament, red. G. Kittel, t. I-X, Stuttgart 19491979 [dalej jako TWNT] imię „Agabos” nie pojawia się wcale.

${ }^{40}$ Typowe dla Septuaginty oraz Nowego Testamentu zjawisko hellenizacji imion semickich, Blass-Deb $\$ 53$.

${ }^{41}$ 1) J 12,33 - w kontekście przepowiedzenia śmierci Jezusa; 2) J 18,32 - w tym samym kontekście; 3) J 21,19 - w kontekście przepowiedzenia śmierci Piotra; 4) Dz 11,28 - jako przepowiadanie głodu; 5) Dz 25,27 - w kontekście mowy Festusa; 6) W prologu Apokalipsy (Ap 1,1) Bóg za pośrednictwem anioła przekazuje Janowi objawienie, zob. WB, 1495.

${ }^{42}$ Zob.: J. Kudasiewicz, „Gdy Duch Święty zstapi na was, otrzymacie Jego moc i będziecie moimi świadkami...” (Dz 1,8; Łk 24,48n). Studium z teologii świętego Łukasza, w: Miłość jest z Boga; W. Rakocy, Duch Święty w poczq̨tkach Kościoła, w: „Duch i Oblubienica mówiq: przyjdź”, Fs. A. Jankowski [AMA], red. W. Chrostowski, Warszawa 2001, 385-389.

${ }^{43}$ Zob .Łk 4,25; 15,14; 21,11; Dz 7,11.

${ }^{44}$ Blass-Deb $§ 356,3$.

${ }^{45}$ U Łk 2,1; 4,5; 21,26; Dz 17,31; 19,27 - jako ludzie w ogólności. W Dz 17,6; 24,5 jako imperium rzymskie. Problem możliwego kontaktu z koncepcją hebrajską porusza E. Hänchen; Die Apostelgeschichte, 359, nota 6.

46 Józef Flawiusz (Ant. 20,51.101.105) mówi o pladze głodu za panowania gubernatora Tyberiusza Aleksandra (46-48 po Chr). W Ant 3,320 mówi o głodzie w całym kraju. Ceny zboża w samym Rzymie bardzo wzrosły, co groziło buntem tłumu przeciwko Klaudiuszowi (51 r.). Około roku 45-46 Helena, królowa Adiabene, kupiła drogie ziarno egipskie by pomóc Judei (C.S. Keener, Komentarz historyczno-kulturowy, 263). 
mają nastąpić, i pozwala wierzącym odpowiednio się na nie przygotować. $\mathrm{Z}$ punktu widzenia czytelnika lub słuchacza opowiadania przepowiednia Agabosa rzeczywiście się dokonała ${ }^{47}$. Samo przepowiadanie wydarzeń przyszłych ewidentnie wiąże działanie Agabosa $\mathrm{z}$ prorokami starotestamentalnymi, a odróżnia od całego szeregu wyroczni i wróżb znanych w kulturze hellenistycz$n j^{48}$. Przepowiadanie przyszłości ${ }^{49}$ jest jedną z ważnych funkcji prorockich w Starym Testamencie, bardzo często związane ściśle z wezwaniem do nawrócenia i pokuty lub z pocieszeniem Izraela przeżywającego trudne chwile. Prorok występuje jako przedstawiciel Boga działającego w historii.

11,29: Uczniowie więc, według możliwości, pośpieszyli, każdy z nich, by posłać pomoc braciom mieszkającym w Judei...

Antiocheńczycy są nazywani „uczniami”"50. Termin ten u Łukasza oznacza zawsze wspólnotę zgromadzoną wokół Jezusa i wszystkich chrześcijan. Spontanicznie decydują się zebrać środki, aby wspomóc chrześcijan w Judei.

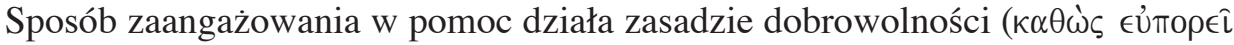

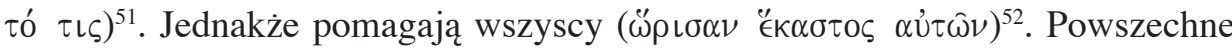
zaangażowanie we wsparcie świadczy o przeświadczeniu o prawdziwości proroctwa Agabosa oraz o głębokiej więzi, która wiąże chrześcijan z Antiochii z Kościołem w Judei.

Pomoc jest kierowana do braci mieszkających w Judei. Wyraz „bracia”

${ }^{47}$ Natomiast trudno znaleźć przesłanki dla tezy, która sugeruje podwójny wymiar czasowy realizacji proroctwa; jako historycznie dokonanego oraz równocześnie posiadającego wymiar eschatologiczny (zob. Łk 21,11), zob. : J. Jeremias, Sabbatjahr und neutestamentliche Chronologie,

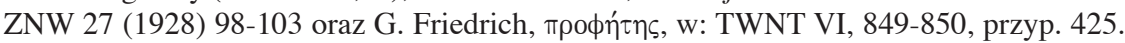

48 Jedną z typowych cech odróżniających prorokowanie izraelskie czy chrześcijańskie od pogańskiego była komunikacja za pomocą niejasnych słów czy znaków (np. na wnętrznościach zwierząt), które wymagały udziału interpretatora lub ich grupy. Dodatkowo, istotną rolę odgrywały formy prorokowania ekstatycznego, w transie, który pozbawiał prorokującego samokontroli

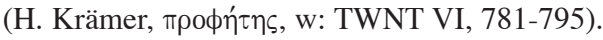

${ }^{49} \mathrm{Na}$ temat przepowiedni, ich znaczenia oraz realizacji - zob. R. Rumianek, Prorocy okresu niewoli babilońskiej, Warszawa 2004, 12-22.

${ }^{50} 261$ razy w Nowym Testamencie, 42 razy u Łk, 28 razy w Dz (sens specyficzny w 19,1). Łukaszowa koncepcja uczniostwa posiada kapitalne znaczenie dla jego teologii, zob. R. O'Toole, L'unità della teologia di Luca. Un'analisi del Vangelo di Luca e degli Atti, Leumann 1994, 57-91.

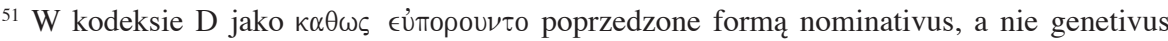
absolutus, jak w tekście wybranym przez $\mathrm{NA}^{27}$. Bez większego wpływu na znaczenie tekstu.

${ }^{52}$ Temat stosunku do własności prywatnej i wspólnej jest traktowany przez Dz w sposób niejednolity. Idealistyczny, typowy dla Jerozolimy, model wspólnego zarządzania dobrami, złożonymi wcześniej u stóp Apostołów, nie znalazł powszechnej akceptacji, zob. M. Karczewski, „Wszystko mieli wspólne” (Dz 2,44b). Pierwsi chrześcijanie wobec dóbr materialnych, Forum Teologiczne 7 (2006) 16-20. 
oznacza innych wierzących w ogólności, czyli wszystkich chrześcijan ${ }^{53}$. Bracia mieszkają w Judei. Braćmi będą także wierzący w Efezie, w Koryncie czy w Rzymie. Przez użycie tego terminu Łukasz podkreśla, że wiara w Jezusa Chrystusa niweluje wszelkie różnice etniczne, usuwając je na drugi plan ${ }^{54}$. Fakt, że jakby w centrum Kościoła Powszechnego są wierzący o żydowskich korzeniach sprawia, że realizują się starotestamentalne zapowiedzi o powszechnej dostępności zbawienia oraz kontynuacji Ludu Wybranego ${ }^{55}$. Sposób pomocy nie jest do końca sprecyzowany. Najprawdopodobniej zebrano środki finansowe. Termin $\delta\llcorner\alpha \kappa о \nu i ́ \alpha$, tłumaczony niekiedy w sposób uproszczony jako „kolekta lub zbiórka", posiada przede wszystkim sens pomocy potrzebującym ${ }^{56}$. Z pewnością nie chodzi tu o instrumentalnie pojmowaną jałmużnę.

11,30: Tak też uczynili, posyłając starszym (prezbiterom) przez Barnabę i Pawta.

Pomoc zostaje przekazana za pośrednictwem Barnaby i Pawła. Barnaba jest ściśle związany ze wspólnotą w Jerozolimie i jest jej wysłannikiem do wierzących w Antiochii (Dz 11,22). Dla Pawła, współpracownika Barnaby, jest to możliwość nawiązania kontaktu z chrześcijanami w Judei. Pomoc dociera do Jerozolimy (Dz 12,25). Zostaje przekazana starszym wspólnoty. Trudno powiedzieć, dlaczego pieniądze nie zostały przekazane Apostołom ${ }^{57}$. Prawdopodobnie termin

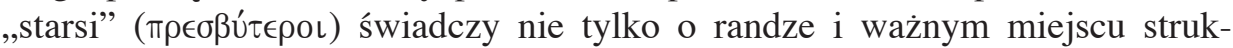
turze wspólnoty, ale także sugeruje pewien typowy dla Dz podział funkcji i odpowiedzialności we wspólnocie chrześcijańskiej (zob. Dz 14,23) ${ }^{58}$.

\subsubsection{Dz $21,10-11$}

Podczas, gdy pozostawaliśmy tam wiele dni, zszedt z Judei jakiś prorok imieniem Agabos $i$ przybywszy do nas, wziquszy pas Pawła $i$ zwiqzawszy nogi

${ }^{53}$ Zob. Dz 1,15; 15,1.3.7.13.40; 16,2, itd.

${ }^{54}$ Zob. J. Dupont, Teologia della Chiesa negli Atti degli Apostoli, Bologna 1984, 12.

${ }^{55}$ Zob. G. Lohfink, Die Sammlung Israels. Eine Untersuchung zur lukanischen Ekklesiologie, München 1975, 93-96.

${ }^{56} 34$ razy w Nowym Testamencie, u Łk - 1 raz, 8 razy w Dz. Sugerowany sens: por.: Dz 6,1; 2 Kor 8,4; 9,1.12.13; Ga 2,10. Zob. WB, 369; J. Dupont, Les Actes des Apôtres, 115, przyp. a.

${ }^{57} \mathrm{Na}$ temat funkcji Apostołów zob. M. Wojciechowski, Funkcje Dwunastu w Dziejach Apostolskich, w: Czynem i prawdq, red. C. Rogowski i in., Olsztyn 2004, 61-68.

${ }^{58}$ W. Rakocy („Będziecie moimi świadkami...”, 60) stwierdza: „termin «starsi» występuje często w Dziejach; brak jednak jakiejkolwiek definicji pełnionej przez nich funkcji”. 
i ręce, powiedziat: tak mówi Duch Święty: męża, którego jest ten pas zwiqża w Jerozolimie Żydzi $i$ wydadzq w ręce pogan.

Dz 21,10-11 stanowi część jednostki 21,1-14, poświęconej ostatnim etapom podróży Pawła do Jerozolimy. Całość opisu podróży mieści się między 19,21 i 21,14 . Wyraźnym etapem tej podróży są wydarzenia związane z jego pobytem

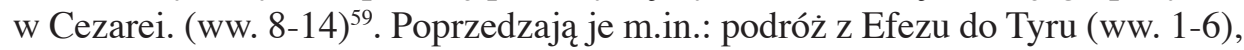
chwilowy postój w Ptolemaidzie (w. 7). Relacja pobytu Pawła w Cezarei zawiera (ww. 8-14);

1) opis przybycia i pobytu w domu Filipa (w. 8),

2) charakterystykę córek Filipa (w. 9),

3) przybycie i proroctwo Agabosa (w. 10-11),

4) reakcję słuchaczy i Pawła, decyzję Pawła o kontynuowaniu podróży (ww. 12-14).

Krótka informacja o córkach diakona Filipa ${ }^{60}$, określonych jako prorokujące, bezpośrednio poprzedza epizod spotkania Pawła z prorokiem Agabosem ${ }^{61}$. Przybycie i proroctwo Agabosa przerywają czas niezmąconego niczym pobytu w Cezarei. Jednocześnie jego kontynuację stanowi opis reakcji apostoła i towarzyszących mu osób. Spotkanie z Agabosem jest ostatnim spotkaniem przed dotarciem do Jerozolimy.

\section{1,10: Podczas, gdy pozostawaliśmy tam wiele dni...}

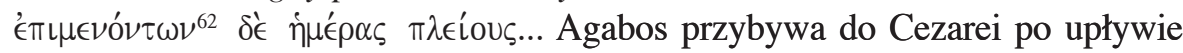
wielu dni od przybycia Pawła i jego towarzyszy, dlatego można przyjąć, że jego przybycie stanowi jakby nową historię. Do tej pory Paweł przechodził przez różne miejscowości. Nadejście kogoś, kto mu idzie naprzeciw i w dodatku przybywa z Judei, sugeruje czytelnikowi/słuchaczowi Dziejów, iż wydarzy się coś istotnego.

zszedt z Judei jakiś prorok imieniem Agabos

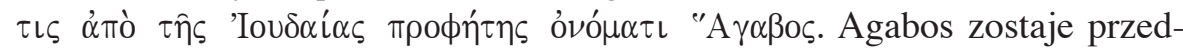

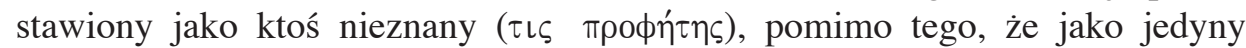
z proroków przybyłych z Judei czynnie wypełniał swoje posłannictwo w 11,2728. Odnosi się wrażenie, że narratorzy, do których odnosi się zaimek osobowy

${ }^{59}$ Dz 20,1-21,26 są zorganizowane jako etapy podróży Pawła. Jednym z nich jest pobyt u Filipa, zob. L. Panier, Parcours: pour lire les Actes des Apôtres. 8éme série. Itinéraire d'Ephése à Jérusalem (ch. 20,1-21,26), SémBib 37 (1985) 42-43.

${ }^{60}$ Działalność Filipa wpisuje się w dzieło ewangelizacji pogan, zob. J. Fervell, The Portrait of Philip in Acts. A Study of Roles and Relations, Fs. Spencer (JSNTSup 67), Sheffield 1992, 135-141.

${ }^{61}$ Wzmianka o dziewicach w kontekście przybycia Agabosa, według Schneidera, prowadzi wyraźnie do kolejnego epizodu, zob. G. Schneider, Gli Atti degli Apostoli, t. 2, 401.

${ }^{62}$ Genetivus absolutus, typowy w różnych odcieniach stylistycznych dla Dz, zob. Blass-Deb $\S 423$. 
„my”, nic nie wiedzą o epizodzie z Antiochii i widzą Agabosa po raz pierwszy (zob. Dz 16,11) ${ }^{63}$. Problem braku spójności w prezentacji tradycji o proroku Agabosie jest jednym $\mathrm{z}$ wielu dowodów na bardzo złożoną historię tekstu i redakcji $\mathrm{Dz}^{64}$. Problem wersji i redakcji tekstu Dz jest poddawany szczegółowej analizie egzegetów. Określenie Agabosa w Dz 21,10 jako kogoś nieznanego świadczy ewidentnie o różnicy źródeł w relacji do pierwszego opisu ${ }^{65}$.

Cechą wspólną pierwszej i drugiej wzmianki o Agabosie jest wskazanie na krainę, z której przybywa i pochodzi. Jest to Judea. W tym przypadku jednak, poza nawiązaniem do starożytnej tradycji prorockiej Izraela oraz do centralnego znaczenia wspólnoty jerozolimskiej, akcent położony jest na wyjście naprzeciw. Paweł zmierza do Jerozolimy. Agabos przychodzi z Judei, w której centrum leży właśnie Jerozolima. Wyjątkowe spotkanie z prorokiem stanowi preludium dramatycznych wydarzeń w życiu Pawła.

21,11: i przybywszy do nas wziquszy pas Pawła $i$ zwiqzawszy nogi $i$ ręce powiedziat:

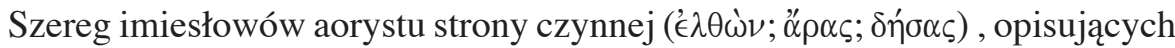
wymowny gest Agabosa, znajduje swoje wyjaśnienie w jego oszczędnej w słowa wypowiedzi $(\epsilon \hat{\imath} \pi \epsilon \nu)$.

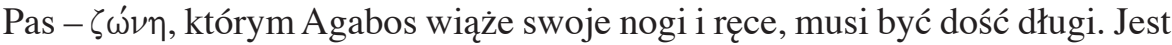
to najprawdopodobniej długi pas tkaniny, którą kilkakrotnie owijano się w talii, a jego fałdy mogły być używane jako prowizoryczne kieszenie ${ }^{66}$. Symboliczny gest Agabosa bez wątpienia nawiązuje do niezbyt częstych, ale wymownych form proroctwa starotestamentalnego, do tzw. proroctw symbolicznych lub mimicznych (zob. $1 \mathrm{Sm}$ 11,6-7; 1 Krl 11,29-39; 22,11; Iz 8,1-4; 20,2-6; Jr 13,1$11 ; 19,1-13 ; 27,1-22 ;$ Ez $4-5)^{67}$. Agabos działa podobnie jak jeden z proroków starotestamentalnych ${ }^{68}$. Jaki sens posiada akcja symboliczna proroka, skoro i tak tę samą prawdę można wyrazić słowami69? Akcja symboliczna zastanawia, angażuje, stanowi zagadkę, a jednocześnie ilustrację. Jest stosowana przede

${ }^{63}$ Tzw. Wir-Stücke - specyficzne dla Dz 16-28, zob. W. Rakocy, „Będziecie moimi świadkami...” (Dz, 1,8), 17-18.

${ }^{64}$ Zob. W. Rakocy, „Będziecie moimi świadkami...” (Dz 1,8), 24.

${ }^{65}$ Zob. E. Hänchen, Die Apostelgeschichte, 575.

${ }^{66}$ C.S. Keener, Komentarz historyczno-kulturowy, 288; R. Pesch, Die Apostelgeschichte, t. 2, 214.

${ }^{67} \mathrm{~Np}$. w 1 Krl 11,29-31 Achiasz z Szilo, rozdzierając płaszcz na dwanaście kawałków, ilustruje nadchodzący rozpad Izraela na Północ i Południe. Zdecydowanie błędne jest dopatrywanie się w prorockich akcjach symbolicznych elementów lub związków magicznych. Zob. J.L. Sicre, I Profeti d'Israele e il loro messaggio (Studi e Ricerche Bibliche), Roma 1989, 43.

${ }^{68}$ Jest ich kontynuatorem, zob. M. Rosik, Duch Święty - źródło odwagi w głoszeniu słowa zbawienia, VV 2 (2002) 154.

${ }^{69}$ Pyta i odpowiada J.L. Sicre, I Profeti d'Israele, 37. 
wszystkim wtedy, gdy prorokowi towarzyszą naoczni świadkowie ${ }^{70}$. Po raz kolejny prorok chrześcijański jest bezpośrednim kontynuatorem proroków starotestamentalnych ${ }^{71}$. Pod względem niechybnego spełnienia się proroctwa sytuacja z Cezarei przypomina spotkanie Maryi z Symeonem i Anną (Łk 2,33$38)^{72}$.

tak mówi Duch Święty:

Intencja nawiązania do stylu proroków starotestamentalnych widoczna

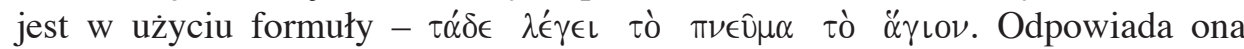
niezwykle często występującej w Starym Testamencie prorockiej formie

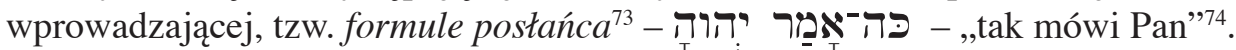
W proroctwie Agabosa jako Bóg przemawia Duch Święty. Utożsamianie działania Ducha Świętego z bezpośrednim działaniem Bożym, i w konsekwencji - podkreślanie Boskiej godności Ducha Świętego, to jedna z cech szczególnych pneumatologii Łukasza, widoczna szczególnie w tekście Dz. Duch Święty uobecnia Ojca i Syna ${ }^{75}$. Z faktem tym związana jest pewna nowość w prorokowaniu chrześcijańskim w stosunku do proroków starotestamentalnych. Pomimo ewidentnej kontynuacji i związków z profetyzmem izraelskim, prorocy chrześcijańscy działają w nowej perspektywie historycznej. Wydarzenie Jezusa Chrystusa, Zbawiciela każdego człowieka, oraz wyjątkowy dar, jakim jest zesłanie Ducha Świętego, mają kapitalne znaczenie również dla rozumienia misji prorockiej Agabosa.

męża, którego jest ten pas, zwiqżq w Jerozolimie Żydzi $i$ wydadza w ręce pogan.

${ }^{70}$ Elementy wspólne proroctw symbolicznych w Starym Testamencie, wyodrębnione przez Fohrera to: nakaz Boga - wezwanie proroka do wykonania konkretnej akcji symbolicznej; opis - pojawia się lub zostaje ograniczony do minimum jako oczywisty; interpretacja - komentarz, który nadaje wydarzeniu jednoznaczną interpretację; zaangażowanie Boga na rzecz realizacji proroctwa - proroctwa symboliczne wypełnią się w sposób bardzo ewidentny; ukryty zwiqzek - między akcją symboliczną oraz jej treścią. G. Fohrer, Die Gattung der Berichte über symboliche Handlungen der Propheten, ZAW 64 (1952) 117. Oczywiście nie zawsze wszystkie elementy występują równoczésnie, zob. J.L. Sicre, I Profeti d'Israele, 37-38.

${ }^{71}$ Jako typowy prorok judaistyczny, zob. E. Fascher, Profetes, 184; H. Patsch, Die Prophetie des Agabus, TZ 28 (1972) 229.

${ }^{72}$ Stan współczesnej dyskusji na temat związków Łk-Dz wyczerpująco omawia M.F. Bird, The Unity of Luke-Acts in Recent Discussion, JSNT 29 (2007) 425-448.

${ }^{73}$ Zob. A. Spraeafico, La voce di Dio (StBi 33), Bologna 1998, 23-29.

${ }^{74} \mathrm{Na}$ temat porównania literackiego między formułą starotestamentową i starochrześcijańską zob. U. Müller, Prophetie und Predigt im Neuen Testament, 45-46.

${ }^{75}$ R. O’Toole, L'unità della teologia di Luca, 24-25. 
Paweł ma zostać związany przez innych, czyli pozbawiony swobody, skrępowany, co jest obrazem jego przyszłego uwięzienia ${ }^{76}$. Los Pawła ma wypełnić się w Jerozolimie. Jerozolima posiada szczególną pozycję w teologii Łukaszowej. Obok wspomnianej już pozycji, skupionej wokół apostołów wspólnoty jerozolimskiej, istnieją także inne istotne powody, by Jerozolimę traktować w sposób wyjątkowy. Zajmuje centralną pozycję w narracji o misji Jezusa, który zmierza ku Jerozolimie, aby oddać życie za grzechy i zmartwychwstać ${ }^{77}$. Ale jest także miastem odrzucenia Jezusa ${ }^{78}$. Od Jerozolimy rozpoczęło się głoszenie odpuszczenia grzechów i działalność ewangelizacyjna Kościoła $^{79}$. Jest ona miastem szczególnym, wybranym przez Boga, jej sercem jest świątynia, która odgrywa szczególną rolę w życiu pierwszej wspólnoty chrześcijańskiej ${ }^{80}$. Jerozolima jest również miejscem pierwszych prześladowań. Paweł został uwięziony wbrew swej woli właśnie wtedy, gdy znalazł się w świątyni (Dz 21,27-28). Paweł, jako dawny przeciwnik, a aktualny propagator chrześcijaństwa, jest szczególnie znienawidzony ${ }^{81}$.

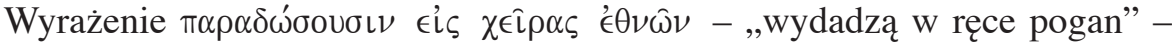
podkreśla poddanie się przemocy innych ldzi i jest typowa dla opisów losu Jezusa (por. Mt 17,22; 26,45; Mk 14,41; Łk 9,44). Żydzi (oi 'Iovó $\alpha i ̂ \iota)^{82}$ są wskazani jako odpowiedzialni za problemy Pawła. Z dużym prawdopodobieństwem intencjonalnie podkreśla się podobieństwo między losem Jezusa i Pawła (zob. Łk 23,1-25 i Dz 25-26) ${ }^{83}$. Przedstawiany przez niektórych komentatorów kontrargument, iż Łukasz nie wspomina o związaniu Jezusa, nie jest wystarczający ${ }^{84}$. Nie jest także wykluczone, że w kontekście szerszym dzieła Łukaszowego zarówno

${ }^{76}$ F. Staudinger, $\delta \in \sigma \mu о \varsigma$, w: EWNT I, 692-696.

${ }^{77}$ B. Prete, L'opera di Luca, 37-43.

${ }^{78}$ J. Kudasiewicz, „, Gdy Duch Święty zstapi na was...”, 205.

${ }^{79}$ Zob. tamże, 196-201.

${ }^{80}$ Motyw świątyni oraz jej interesującą wizję teologiczną w kontekście Dz omawia szeroko G.K. Beale, The Temple and the Church's Mission. A biblical theology of the dwelling place of God (New Studies in Biblical Theology), Downers Grove 2004, 201-244.

${ }^{81}$ Paweł jest szczególnym obiektem ataków zwolenników judaizmu, W. Rakocy, „Będziecie moimi świadkami...” (Dz 1,8), 64-67.

82 Relacja Synagogi do Kościoła chrześcijańskiego w Dz od początku znaczona była nawróceniami niektórych znakomitych jej członków, ale również silną presją ze strony większości jej autorytetów, by chrześcijaństwo jak najprędzej wyeliminować, zob. W. Rakocy, Obraz $i$ funkcja, 177-206. Na temat szerszego kontekstu głoszenia Ewangelii Żydom, ich wybraństwa i odrzucenia - zob. A. Vanhoye, Les Juifs selon les Actes des Apôtres et les Épîtres du Nouveau Testament, Bib 72 (1991) 70-89.

${ }^{83} \mathrm{O}$ tym i innych tekstach, np. opisie męczeństwa Szczepana, mówi R. O’Toole, L'unità della teologia di Luca, 57-81. Podobieństwo form czasownikowych omawia J. Smit Sibinga, The Function of Verbal Forms in Luke-Acts, FN 6 (1993) 31-50.

${ }^{84}$ Zob. H. Patsch, Die Prophetie des Agabus, 231. 
historia Jezusa, Pawła, jak i Piotra pozostają w pewnej relacji do opowiadań o Eliaszu i Elizeuszu, głoszących słowo Boże pomimo wielu przeciwności (zob. $1 \mathrm{Krl}$ 17,17-24; $2 \mathrm{Krl}$ 4,18-37) ${ }^{85}$.

Interesujące, że Agabos bezpośrednio nie wydaje żadnego nakazu czy zakazu dotyczącego dalszej podróży Pawła do Jerozolimy, lecz jedynie przepowiada przyszłość. Odnosi się wrażenie, że Agabos pozostawia podjęcie decyzji Pawłowi. Już podczas pobytu Pawła w Tyrze niektórzy chrześcijanie pod

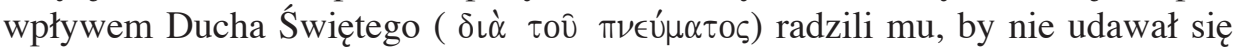
do Jerozolimy (Dz 21,4; zob. 20,23). Czy ostrzeżenia chrześcijan w Tyrze były jakąś formą proroctwa, nie jest jasne ${ }^{86}$. Po raz kolejny Łukasz nie precyzuje, co tak naprawdę się dokonało, akcentując jedynie działanie Ducha Świętego oraz los Pawła.

W reakcji na proroctwo Agabosa towarzysze Pawła i ,miejscowi" 87 chrześcijanie proszą go, by zmienił plany i nie szedł do Jerozolimy (w. 12). Jednakże Paweł jest gotów nie tylko ponieść więzy, lecz również umrzeć ( $\propto$ mỏ $\theta \alpha \nu \in \hat{\imath} \nu)^{88}$ z powodu Jezusa (w. 13) ${ }^{89}$. Przekonanie o konieczności udania się do Jerozolimy pomimo grożącego mu niebezpieczeństwa jest związane z chęcią realizacji woli Pana (w. 14) ${ }^{90}$. Proroctwo Agabosa było zatem objawieniem zamiarów Pana wobec Pawła, zgodnym z celem jego powołania (zob. Dz 9,15-16; $22,17-21 ; 23,11 ; 26,16)$.

W odróżnieniu od pierwszego opisu działania Agabosa we wspólnocie w Antiochii, gdzie następuje natychmiastowa pozytywna reakcja, w Cezarei uczniowie mają poważną trudność, by te plany zaakceptować. Czują się związani z Pawłem. Reagują bardzo emocjonalnie. Widać wyraźnie, że posługa Pawła bazuje na silnej więzi międzyosobowej, z drugiej strony - sprzeciw chrześcijan wobec rozstania z Pawłem wpisuje się w kontekst innych relacji dotyczących pierwotnego Kościoła jako wspólnoty miłości braterskiej i zaufania.

85 Sugestię taką opierając się na interpretacjach wczesnochrześcijańskich przedstawia H. Marshall, Acts, 596.

${ }^{86}$ Zob. G. Schneider, Gli Atti degli Apostoli, t. 2, 400; J. Dupont, Les Actes des Apôtres, 181, przyp. c.

${ }^{87}$ Zob. WB, 544.

${ }^{88} \mathrm{U}$ Łk - 10 razy, w Dz - 4 razy jako umierać. Zob. WB, 182-183.

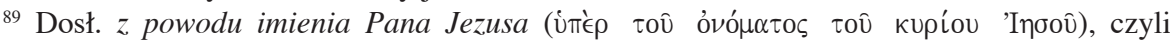
z powodu wiary w Jezusa jako Syna Bożego.

${ }^{90} \mathrm{~W}$ kulturze hellenistycznej wyrocznie miały za zadanie ostrzec przed nieszczęściem. W tekście Dz nie ma jednak żadnej wzmianki o tym, że Agabos radzi Pawłowi, by ten nie szedł do Jerozolimy, C.S. Keener, Komentarz historyczno-kulturowy, 288. 


\subsection{Agabos jako postać historyczna}

\subsubsection{Postać Agabosa na tle Łukaszowej koncepcji historii}

Postać Agabosa jest tylko jedną z wielu przedstawionych w dziele Łukaszowym. Występuje wyłącznie w kontekście Dz. Podobne przypadki spotyka się w całym tekście Łukaszowym ${ }^{91}$. Na próżno poszukiwać w innych tekstach nowotestamentowych takich postaci, jak: Symeon, Anna, Kleofas, Korneliusz, Lidia czy wiele innych. Jawi się pytanie - na ile, wobec bardzo ewidentnego kolorytu teologicznego, informacje o Agabosie mogą być historycznie prawdopodobne? Jakie jest ich podstawowe znaczenie?

Dyskusja egzegetów na temat historycznego wymiaru treści Dz prowadzona jest $\mathrm{z}$ wielką uwagą i respektem wobec konkretnych jednostek literackich oraz ich roli w uwydatnieniu głównych myśli teologicznych autora biblijnego ${ }^{92}$. $\mathrm{Z}$ jednej strony, w treści Dz spotyka się niezaprzeczalne fakty historyczne znane $\mathrm{z}$ innych źródeł historycznych ${ }^{93}$. Dyskutuje się również na temat możliwych zależności stylu Dziejów od innych pism hellenistycznych o charakterze historycznym $^{94}$. Z drugiej jednak strony, niewątpliwie centralnym wydarzeniem historii jest przyjście Jezusa Chrystusa ${ }^{95}$. Oryginalnie formułowana eschatologia jest kolejnym wymiarem, który nabiera swojej dynamiki szczególnie w kontekście Dz. Opisy faktów historycznych są głównie nośnikami treści religijnej (historia kerygmatyczna) ${ }^{96}$. Wydaje się zatem, że opisy działania Agabosa są przede wszystkim jedną z ilustracji dotyczących działania Boga w Kościele i jego miejsca w historii zbawienia. Samo nadanie Agabosowi cech typowych dla proroka starotestamentalnego ${ }^{97}$ uwydatnia istotną cechę teologii Łukaszowej, którą jest podkreślanie kontynuacji między Starym i Nowym Testamentem. Dodatkowo

${ }^{91}$ Jedną z cech charakterystycznych świadczących o jedności literackiej Łk-Dz jest sposób podejścia do historii, zob. J. Schröter, Lukas als Historiograph. Das lukanische Doppelwerk und die Entdeckung der christlichen Heilsgeschichte, w: Die antike Historiographie und die Anfänge der christlichen Geschichtsschreibung, (BZNW 129), red. E.-M. Becker, Berlin 2005, 242-246.

${ }_{92}$ Zob. J. Kudasiewicz, „, Gdy Duch Święty zstapi na was...”, 204-206.

${ }^{93}$ W. Rakocy, „Będziecie moimi świadkami...” (Dz 1,8), 24-26.

${ }^{94}$ Zob. Die Apostelgeschichte und die hellenistische Geschichtsschreibung, Fs. E. Plümacher (Ancient Judaism and Early Christianity 57), red. C. Breytenbach - J. Schröter, Leiden - Boston 2004.

${ }^{95}$ Relację między koncepcją czasu a osobą Jezusa w kontekście dzieła Łukaszowego omawia B. Prete, L'opera di Luca, 11-16.

${ }^{96}$ Zob. W. Rakocy, „Będziecie moimi świadkami...” (Dz 1,8), 16. 33-34.

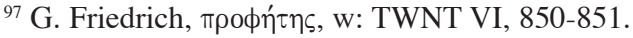


wyraża ponadetniczną więź, która powoduje przynależność do jednego, wielonarodowego Kościoła. Dodatkowo należy wspomnieć, że w działanie Agabosa wskazuje jasno, że Jerozolima odgrywa w dziele ewangelizacji szczególną rolę. W historii posługi apostolskiej Pawła Agabos staje się ogniwem w łańcuchu zdarzeń, które pozwolą Pawłowi najpierw pogłębić kontakty ze wspólnotą jerozolimską, a następnie składać świadectwo wobec Rzymian ${ }^{98}$.

Wydaje się zatem, że epizody dotyczące Agabosa posiadają przede wszystkim znaczenie teologiczne, choć nie da się wykluczyć ich związków z historią ${ }^{99}$. Obecność w pierwotnym chrześcijaństwie nurtu tzw. proroków wędrownych zdaje się potwierdzać te związki i umożliwia przyjęcie hipotezy, że Agabos jest kimś podobnym do proroków wspominanych we wczesnych źródłach patrystycznych.

\subsubsection{Agabos a prorocy chrześcijańscy w świetle Didache i Pasterza Hermasa}

\section{Didache}

Didache jest jednym z pierwszych świadectw czasów poapostolskich, potwierdzającym istnienie proroków chrześcijańskich ${ }^{100}$. Jako środowisko historyczno-geograficzne powstania Didache wymienia się Syrię ${ }^{101}$, Egipt lub Palestynę ${ }^{102}$. Centralnym tematem Didache jest liturgia ${ }^{103}$. Z pewnością można znaleźć pewne punkty wspólne Didache i Dz ${ }^{104}$. Należy do nich także istnienie proroków chrześcijańskich. Prorocy należą do przewodniczących wspólnocie ${ }^{105}$. Pomimo zaplanowanego porządku liturgii, prorok może rozpocząć modlitwę dziękczynną po Eucharystii w sposób spontaniczny ${ }^{106}$. Autentyczność jego

\footnotetext{
${ }^{98}$ Hipotezę, według której Łukasz kieruje swoje orędzie do Rzymian, przedstawia J. Kilgallen, Luke wrote to Rome - a Suggestion, Bib 88 (2007) 251-255.

${ }^{99}$ W. Rakocy, „Będziecie moimi świadkami...” (Dz 1,8), 16. 24.

${ }^{100}$ Zob. A. Hamman, Profeta, w: Dizionario patristico e di antichità cristiane, red. A. Di Bernardino, Casale Monteferato 1983, 2914-2915.

${ }^{101}$ Zob. J.A. Draper, Torah and troublesome apostles in the Didache community, NovT 33 (1991) 347.

102 Zob. D.G. Lange, The Didache: Liturgy Redefining Life, Worship 78 (2004) 207.

103 Tamże, 208-210.

${ }^{104} \mathrm{Na}$ bliskie związki między Didache i Dz wskazuje m.in. C.N. Jefford, Tradition and witness in Antioch: Acts 15 and Didache 6, PRSt 19 (1992) 409-419.

105 Por. Did 13,1-7. Niektórzy poddają pod wątpliwość możliwość faktycznego oddzielenia funkcji apostołów, proroków i nauczycieli, sugerując synonimiczne użycie tych terminów lub ich wspólną charyzmatyczną naturę, zob. G. Kretschmar, Ein Beitrag zur Frage nach dem Ursprung frühchristlicher Askese, ZThK 61 (1964) 37-38; J.A. Draper, Torah and troublesome apostles, 350.

${ }^{106}$ Podana jest konkretna modlitwa dziękczynna, zob. Did 10,7.
} 
przepowiadania potwierdza praktyka jego życia. W przypadku praktykowania fałszywego świadectwa, zostaje popełniony grzech, który nie będzie odpuszczony ${ }^{107}$. Podobnie jak w przypadku innych nauczających, o prawdziwości jego przepowiadania świadczyć ma zgodność z oficjalną nauką ${ }^{108}$. W przypadku fałszywego nauczania, prorok nie powinien być wysłuchany. O fałszywych intencjach proroka świadczyło także oczekiwanie wynagrodzenia materialnego za wygłoszone proroctwo ${ }^{109}$. Są oni jakby „arcykapłanami” godnymi wszelkiego szacunku, dlatego prawdziwych proroków należy wesprzeć, ofiarując im wino i żywność. Gdy nie ma proroków, zebrane środki należy przekazać biednym ${ }^{110}$.

Motyw możliwości wyłudzenia środków materialnych świadczy o istnieniu praktyk nadużywania funkcji proroka. Sugeruje także możliwość przyjęcie proroków-gości, nieznanych przybyszy z zewnątrz. Również Agabos przybywa z zewnątrz do Antiochii i Cezarei. Temat wynagrodzenia nie pojawia się jednak. Przeciwnie, działanie Agabosa zaowocowało udzieleniem pomocy wielu braciom z Judei. W drugim przypadku, proroctwo Agabosa jest potwierdzeniem i ugruntowaniem wizerunku Pawła w jego szczególnej misji jako więźnia Rzymu.

\section{Pasterz Hermasa}

Pasterz Hermasa jest kolejnym źródłem wczesnochrześcijańskim, potwierdzającym istnienie zjawiska profetyzmu chrześcijańskiego. Kontekst powstania, charakteru literackiego i oddziaływania Pasterza Hermasa jest nieco inny niż Didache czy Dziejów Apostolskich. Dzieło powstało bowiem w środowisku rzymskim i posiada wiele cech, które zbliżają je do apokaliptyki chrześcijańskiej ${ }^{111}$. Również w Pasterzu Hermasa pojawia się tematyka proroctwa chrześcijańskiego. Hermas, który sam miał wizje, nie nazywa siebie nigdy prorokiem. Prorocy nie należą do kierujących Kościołem. Są nimi biskupi, jako sprawujący urząd apostolatu, nauczyciele i diakoni ${ }^{112}$. Prorocy otrzymują Ducha Świętego. Jego natchnienia powinni oczekiwać podczas modlitwy wspólnoty. Hermas dowiaduje się, jakie są kryteria rozpoznania autentycznego powołania prorockiego ${ }^{113}$. Pierwszym kryterium jest sam sposób życia

\section{${ }^{107}$ Did 11,7-9.}

${ }^{108}$ Did 11,1-2; zob. J.A. Draper, Torah and troublesome apostles, 351. Według niektórych, zgodność z nauczaniem apostołów nie miała charakteru dogmatycznego, w kontekście Did trudno jednak przyjąć taką propozycję, zob. K. Wengst, Didache, Barnabasbrief, Zweiter Klemensbrief, Schrift an Diognet, Darmstadt 1984, 36-37.

109 „,srebro lub inne rzeczy” (Did 11,12). Prawdziwy prorok nie żyje z proroctwa (Did 11,9$)$.

${ }^{110}$ Did 13,3 .

111 Zob. G.F. Snyder, Hermas, w: ABD III, 148.

${ }^{112}$ Herm III 5,1.

113 Herm XI,8. Wyczerpującą charakterystykę proroctwa chrześcijańskiego w świetle mandatum XI Pasterza Hermasa przedstawił J. Reiling, Hermas and Christian Prophecy: A Study of the Eleventh Mandate (NovTSup 37), Leiden 1973. 
proroka. Drugim konkretnym wymogiem jest zgodność nauczania prorockiego z wolą Boga, czyli z nauką chrześcijańską ${ }^{114}$. Kolejnym sprawdzianem jest styl posługiwania proroka. Prorok poszukujący własnej chwały lub pieniędzy za wygłoszone proroctwo nie może głosić autentycznego proroctwa ${ }^{115}$.

Jest to zatem kolejne ciekawe świadectwo działania proroków chrześcijańskich. Żadna z tych kwestii nie dotyczy wprost Agabosa, choć niektóre z nich można odnaleźć w innych tekstach Dz dotyczących proroctwa (Dz 13,1-3). Pewien związek odnajdujemy w wymogach, który doskonale spełnia Agabos, kwalifikując się jako prorok autentyczny. Dotyczy to zarówno realizacji proroctw zgodnych z wolą Bożą, jak i tych z brakiem odniesienia do jakichkolwiek kwestii wynagrodzenia. Z drugiej strony, temat wynagrodzenia nie pojawia się w żadnym tekście Łukaszowym związanym z proroctwem chrześcijańskim.

\section{Zakończenie}

Uważna lektura tekstów Łukasza dotyczących postaci proroka Agabosa okazuje się być swoistą ucztą duchową. Dotykamy jakby najbardziej oryginalnych, typowych dla Łukasza, treści teologicznych. Fundamentalne przesłanie teolo-giczne jest następujące: działanie Boga w historii za pośrednictwem proroków nie ustało. Trwa nadal, i to w stopniu zwielokrotnionym w stosunku do epoki przed Chrystusem. Działanie prorockie prowadzi do realizacji starotestamentalnychzapowiedziopowszechnymzbawieniu,proklamacji odpuszczenia grzechów wszystkim narodom, także tym, które z politycznego punktu widzenia są wrogami historycznego Izraela. Nowy Izrael, nowy lud Boży, wyrasta ze starotestamentalnej historii zbawienia, ale dzięki Duchowi Świętemu ogarnia coraz to szersze rzesze ludzi. Prorok działa na korzyść wzmacniania wewnętrznych więzi między chrześcijanami o pochodzeniu żydowskim oraz tymi, którzy Żydami nie są. Więź ta wyraża się w konkretnej pomocy materialnej w momentach trudnych. Związek Agabosa z Pawłem, aczkolwiek epizodyczny, wzmacnia przekonanie, że losy Pawła, podobnie jak innych apostołów czy zwolenników Jezusa, są ściśle związane z działaniem Boga w historii. Nawet sytuacje uwięzienia czy kryzysu paradoksalnie mogą być doskonałą okazją do wypełniania najważniejszej życiowej misji - bycia świadkami Jezusa Zmartwychwstałego i głosicielami Jego Dobrej Nowiny. Najprawdopodobniej Agabos pozostaje także w pewnym związku z potwierdzo-

\footnotetext{
${ }^{114}$ Herm XI,7-10.

${ }^{115}$ Fałszywe proroctwo pochodzi od Złego (Herm X,4-5; XI,12-15).
} 
nym we wczesnych źródłach poapostolskich chrześcijańskim ruchem prorockim. Jedną z jego cech było przemieszczanie się tzw. proroków wędrownych, a ich działalność była jednym z elementów wzmacniających więź poszczególnych wspólnot lokalnych.

Należy wyrazić nadzieję, że ta krótka refleksja teologiczno-biblijna pozwoli Czytelnikowi odkryć kolejne poziomy głębokiej i jakże świeżej, także w naszych czasach, teologii w wydaniu św. Łukasza. 


\section{Riassunto}

Il titolo dell'articolo Il profeta Agabos negli Atti degli Apostoli suggerrisce che il breve studio teologico-biblico viene dedicato al profeta Agabos. Nella Bibbia Agabos appare due volte nel testo degli Atti degli Apostoli (At 11,27-30 e 21,1011). Interessante che nel secondo testo si parla di lui senza articolo, siccome egli fosse una persona sconosciuta. Inoltre dal punto di vista teologico la persona di Agabos accumula diverse interessanti caratteristiche teologico-bibliche tipiche per Luca. Come un'introduzione vengono brevemente analizzati tutti i brani di Luca legati al problema del profetismo cristiano . Segue poi l'analisi esegetica dei testi dedicati direttamente al Agabos. Il primo testo presenta Agabos come coinvolto della storia dei contatti tra i cristiani in Giudea e la giovane communità cristiana ad Antiochia. Nel testo secondo Agabos appare duratne l'utimo viaggio di Paolo a Gerusalemme. La sua profezia ha la forma di una profezia mimica e simbolica, tipica per alcuni profeti veterotestamentali. Come l'ultimo problema viene presentato lo stato della discussione sul tema della relazione tra il testo degli Atti e la realtà storica e le possibili connotazi con Didache e Pastore di Erma. Il quadro di Agabos, molto riccho da parte teologio-biblica porta un'importante messaggio di continuità. Agabos agisce sempre tra due o poli: tra l'Antico e il Nuovo Testamento, tra i cristiani provenienti dal giudaismo e dal paganesimo. Stupisce anche l'attualità del messaggio legato ad Agabos. 